Article

\title{
Place-Keeping for Health? Charting the Challenges for Urban Park Management in Practice
}

\author{
Jinvo Nam $@$ and Nicola Dempsey *(1) \\ Department of Landscape Architecture, University of Sheffield, The Arts Tower, Western Bank, \\ Sheffield S10 2TN, UK \\ * Correspondence: n.dempsey@sheffield.ac.uk; Tel.: +44-114-222-0616
}

Received: 26 June 2019; Accepted: 6 August 2019; Published: 13 August 2019

\begin{abstract}
There is a growing body of evidence that demonstrates the health and well-being benefits of urban green spaces. There is less evidence on the effect of the management of such spaces on our health and well-being. This paper attempts to address this gap in knowledge by calling on empirical evidence collected in the United Kingdom (UK) city of Sheffield. Interviews conducted with professionals and community groups involved in the management of six district parks are analysed using the place-keeping analytical framework. The results highlight the overriding importance of local and national policy regarding how they inform the availability of funding, which is increasingly dependent on partnerships, and governance arrangements to contribute to a park's maintenance, which is monitored through evaluation. The findings show how policies without funding can jeopardise the effective management of parks and how the concept of making park management a statutory service might have more traction if we consider its contribution to people's health.
\end{abstract}

Keywords: urban green space; park management; place-keeping; long-term management; health; well-being

\section{Introduction}

With increasing urbanisation comes concerns about how it adversely affects people's mental and physical health [1]. Urban parks are examples of publicly accessible green spaces that have the potential to contribute positively to our mental and physical health by providing nature and space in densely built-up areas. Urban parks have been found to help improve users' restorative experiences [2,3], reduce mental stress [4], promote recovery from attentional fatigue [5], and contribute positively to psychological well-being [6]. In addition to mental benefits, engaging in physical activity in urban parks can have a beneficial impact on people's health [7]. Furthermore, urban parks can provide settings for social interaction, which can contribute positively to people's sense of place attachment [8]. Activities specific to urban green spaces, such as community gardening, can have positive benefits for mental and physical health [9]. However, these health benefits are based on an assumption that urban parks and green spaces are well-managed and maintained. We aim to explore the underpinnings of this assumption by positing the hypothesis that if urban green spaces are poorly managed, they will not contribute positively to people's health and well-being. Urban green spaces such as parks can feel uncared for if there is inadequate maintenance and management. This has been explored through the "broken window syndrome", in which poor management has been shown to lead to more severe anti-social and criminal behaviour [10] as well as significant declines in quality green space [11], which are difficult and costly to rectify. In light of the increasing global recognition of the part that natural urban green spaces such as parks play in contributing positively to public health [12-14], the importance of green space management should not be overlooked. Green space management is widely acknowledged around the world as contributing positively towards 
sustainable development $[15,16]$ and the long-term liveability of places $[17,18]$. However, such positive contributions can be jeopardised when changes occur in policy contexts, resulting in reduced finance and resources [19]. This is acute at the moment, as the global financial crisis and subsequent austerity have disproportionately affected the non-statutory service of green space management. This can lead to negative perceptions by park users $[20,21]$ that manifest in the non-use of parks. Therefore, we are interested in the part that urban green space managers play in providing healthy places that make people feel safe, comfortable, and drawn to visit.

To understand the importance of green space management for our health and well-being, a number of theoretical or analytical frameworks can be applied. For instance, MacKenzie et al. (2018) [22] emphasized a framework that takes governance as a primary role in green space management [23] and the importance of harnessing the community [24]. Their framework underpins the level of stakeholder interest in participation during decision-making. An extended focus on governance is also found within the Policy Arrangement Approach framework (PAA) [25], which was originally developed in conjunction with policy arrangements rather than governance directly [26]. The PAA has recently been employed to scrutinise aspects of green self-governance practices [27]. With an emphasis on partnership, multiple stakeholders or groups are recognised as having varying roles and responsibilities for green space management [28], as shared responsibility is often associated with partnerships [29,30]. However, there is a need for a framework that is appropriate for evaluating a wider conceptualisation of management [31], because green space management involves multiple dimensions [24,28]. In addition, a useful framework is one that recognises that there are differences in activities between the different stages of landscape design, planning, and management. Place-making-when capital investment is spent-takes centre stage in urban planning and design, when places are created, shaped, and regenerated in towns and cities all over the world [32]. Place-keeping is what happens after such high-quality places have been created [33], referring to the long-term management, which is often taken for granted. Therefore, it is argued here that in order to understand the health and well-being implications of urban park management in practice, a holistic approach to analysis must be applied. We will use the place-keeping analytical framework to examine the hypothesis that poorly managed urban green spaces contribute negatively to people's health and well-being. By exploring a range of issues that emerge when conceptualising urban parks as healthy urban landscapes, place-keeping provides a useful starting point to show how different dimensions of management can contribute positively and negatively to the health and well-being benefits of park users.

\section{Place-Keeping: In the Pursuit of Effective Urban Park Management}

The notion of 'place-keeping' was introduced by Wild et al. [34], and asserts how long-term management has the potential to bring positive environmental, social, and economic benefits for future generations [35]. Place-keeping is a normative concept that explores how the qualities and benefits brought about through the initial place-making process can be enhanced and maintained through long-term management. The focus on place-making is deeply ingrained with policy-makers and practitioners, and underpinned by a wealth of design and planning guidance that tends to consider what comes after the implementation as a postscript [36]. Two reasons may be attributed to this short-term approach to design, planning, and management: firstly, local government budgets are annual, which precludes a long-term view; and secondly, the provision and ongoing management of green and open spaces is not a statutory obligation in many countries around the world. In reality, this means that when budgetary constraints are imposed, public space management and maintenance are disproportionately and adversely affected.

Place-keeping is not simply about the upkeep of the physical changes made to a site; rather, it incorporates a range of interrelated dimensions that can deliver the effective sustainable management of healthy urban landscapes. Figure 1 shows how the overarching framework of place-keeping is conceptualised. 


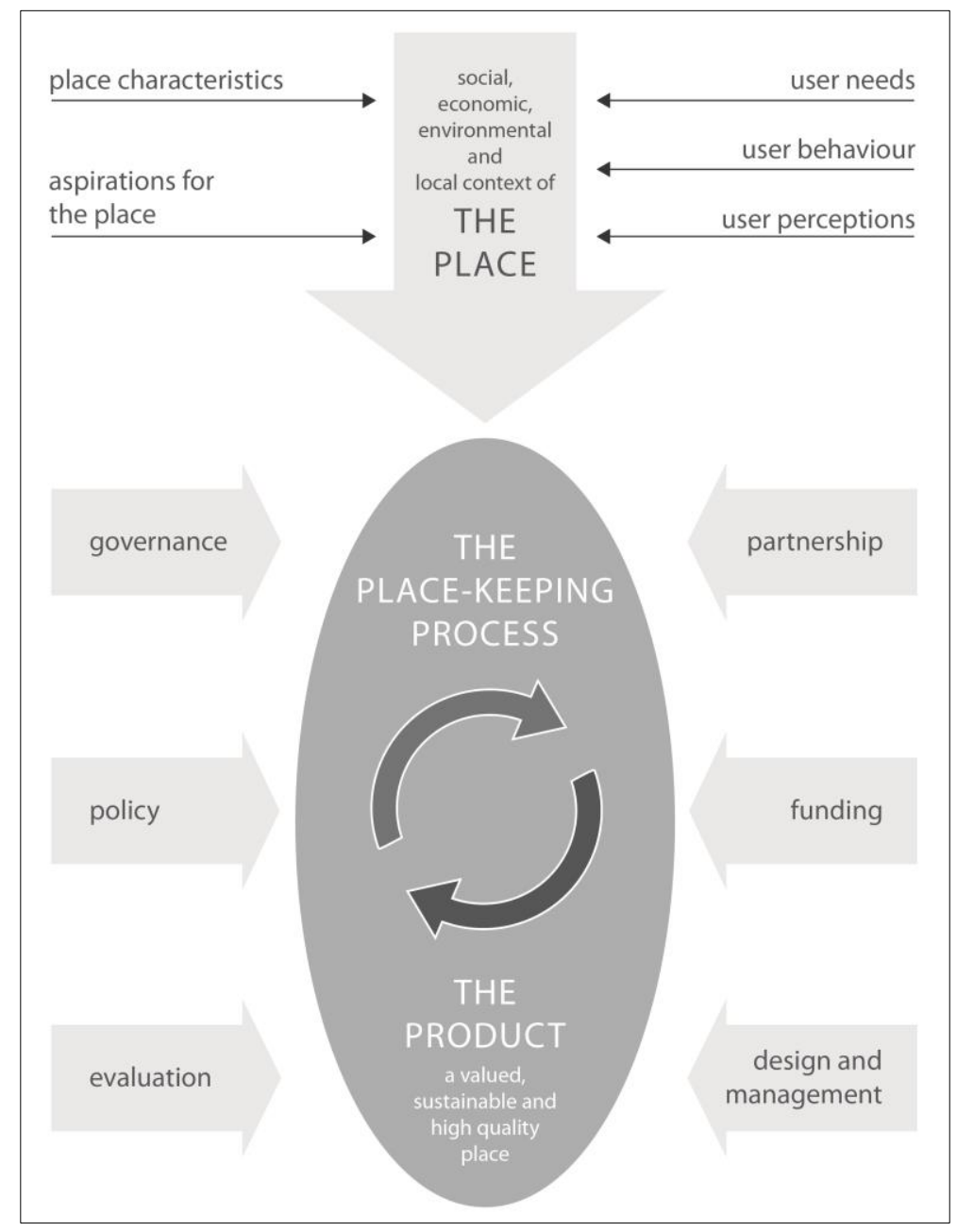

Figure 1. The place-keeping framework (Dempsey and Burton, 2012) [33].

A worked example is helpful here: the day-to-day maintenance activities that are required to look after a park will involve various land management techniques (e.g., grounds maintenance, arboriculture, horticulture), a range of stakeholders (e.g., park manager and staff, park users, local community groups), and varying levels of available resources (e.g., grant funding, income generation, local fundraising). There will also be a need to follow specific regulations to ensure the health and safety of park users (e.g., in playgrounds and around trees) and to undertake some form of evaluation, however minor. All of these elements require co-ordination, which may manifest itself in a long-term strategy document or a site-specific management plan. Historically, despite not being a statutory service, the public sector has largely driven the provision and management of urban green spaces [37]. This ranges from the large-scale public parks of the 19th century to programmes to establish small green spaces in highly urbanised areas around the world [38,39]. A growing body of research is critically examining the legacy of policy-driven green space management $[35,40,41]$, identifying the impact of changing policy contexts. Levels of political support and accompanying funding for urban green space wax and wane over time $[40,42,43]$, which can have a detrimental effect on their quality, negatively affect their use, and potentially reduce the potential health benefits [44]. Recent changes in United Kingdom (UK) policy have emphasised the decentralisation of responsibility [45], which influences the context within which green space management is conducted as more non-state stakeholders become involved [27].

In the current era of austerity, the lack of sustained public funding for parks is a critical issue in the UK [43]. Funding is fundamental to effective place-keeping to ensure that sites are well-managed 
over time. The current neoliberal trends towards contracting out (in and beyond the UK [46]) can adversely affect the management of parks, and highlight how more generic grounds maintenance tasks are prioritised over those requiring more (costly) skills and experience [47,48]. Seeking out sustainable income generation is one approach taken by local governments to address gaps in revenue funding $[45,47]$. This is increasingly extended to include stakeholders such as the community and private sectors. For example, Newcastle has recently applied a charitable trust model to manage a number of its city's parks [49]. There is also a growing reliance on volunteers to take on more responsibility for green space management [50]. There are claims that volunteering can contribute positively to people's mental health [51]; however, this is not fully examined, given the potential pressures that ensue when taking on responsibilities once held by the state sector [52].

There is a wider range of stakeholders involved in urban green space management than ever before. This includes the public sector, the state working in partnership with the private sector (e.g., business improvement districts around the world), voluntary and third sector organisations, as well as individual volunteers [37]. UK park management is largely carried out by the public sector, with increasing use of external input from contractors [53] and the voluntary involvement of local community groups. The use of contractors is a legacy of the Compulsory Competitive Tendering (CCT) introduced in the UK in 1980 [36], opening up the market to the private, public, and/or third sector, allowing them to bid competitively to deliver parks management [54].

Current UK policy puts a strong focus on community engagement [55], which is an ideal derived from participatory governance [56]. This calls on community groups that may already be involved in park management, and can often be driven by a desire to improve their local green spaces [33,46,57]. The implications of the reliance on volunteers have not yet been fully examined in the parks context in the UK to date, although recent research examined collaborations building on citizens' engagement in Berlin, Amsterdam, and Milan [27]. Buizer and Van Herzele found that volunteers don't necessarily represent all the citizens living in an area [58], which is echoed by Mathers et al., who found that green space community groups are largely made up of retired, older white residents [46]. De Magalhães and Trigo pointed out that different governance processes can lead to a reallocation of rights, which prioritises the attributes they (e.g., community group/private sector contractor) have because of their direct involvement in the decision-making [53]. Pillemer et al. (2010) highlighted that many older people who volunteer do it for the well-being benefits gained through positive social interaction [51], while others do it to address pressing environmental issues that affect public health [51,59].

Some green space community groups get involved in maintenance tasks in their local park such as litter picking, which is closely associated with the perceived quality of public spaces [60]. Others get involved in physically demanding activities such as tree planting and riverside vegetation management [59]. Maintenance tasks are related to changes over time, reflecting seasonal use, vegetation growth and user requirement; for example, European parks are more heavily used in the summer than winter months. This means that it is important to conduct maintenance at the right time rather than use a measure based on the amount of work completed [45]. Problems arise in sustaining parks maintenance when budgets are cut, and some of these derive from the legacy of CCT policy in the UK [61]. CCT led to widespread "contracting-out" of maintenance, reducing the majority of tasks undertaken by skilled parks staff to grounds maintenance [48].

Grounds maintenance is one green space management task that is relatively easy to measure (compared to, e.g., the effectiveness of a partnership), and therefore often forms part of maintenance contracts or informal agreements. This ease of measurement means that the green space management can be evaluated to ensure that associated economic, social, and environmental benefits of parks are delivered [62]. Evaluations of green space management in the UK are often measured by existing awards or competitions such as The Green Flag Award, which assesses the maintenance and management of public green spaces $[63,64]$ and can contribute to raising standards [64]. However, real-world evaluations of green spaces cost a significant amount of time and money due to the need to conduct them regularly. Local governments currently do not have the people, resources, and time to evaluate 
parks management [21], and it is unclear to what extent volunteers have the capacity or propensity to engage in such management tasks, given the observation that citizens want to play a "worthwhile role ... [in] ... activities that are genuinely important to them" [65].

The discussion above has set out the different aspects of green space management when conceptualising it holistically. Effective place-keeping in this way requires an understanding of how these aspects, or dimensions, can be coordinated, acknowledging the overlapping nature of partnerships, governance, funding, evaluation, policy, and maintenance. By analysing these aspects through the lens of place-keeping, we can better understand the interactions between the dimensions. Therefore, successfully coordinated place-keeping would consist of long-term quality and efficiency based on stakeholder engagement that has both a strategy and a local focus, which is underpinned by reliable funding sources and a regular evaluation process [33]. However, coordinating place-keeping faces barriers and difficulties such as uncertainty over time and resources, changes in funding or unstable funding challenges, and the imbalance between under-management or over-management in practice $[64,66]$. Therefore, this research examines place-keeping in practice in six parks in Sheffield to understand how it is affected by the past and current social, political, economic, and environmental contexts.

\section{Materials and Methods}

\subsection{Surveys of Community Groups and Professionals}

We conducted semi-structured interviews with 11 professionals and six green space community groups that are currently involved in district park management in six sites in the city of Sheffield, UK (Table 1). The parks were selected according to type (district park), extent of deprivation in the area (to examine any differences between affluent and deprived parts of the city), and the presence of a community group.

Table 1. The practitioner interviewees.CEO: chief executive officer.

\begin{tabular}{|c|c|c|}
\hline & Coded Identifier & Community or Affiliation Name/Position \\
\hline \multirow{6}{*}{ Professionals } & ProSE & Third-sector social enterprise/CEO \\
\hline & ProLA-1 & Local government (SPCS)/Deputy Head \\
\hline & ProLA-2 & Local government (SPCS)/Community Partnership Manager \\
\hline & ProAC-1 & University/University Academic \\
\hline & ProAC-2 & University/Landscape Research Associate \\
\hline & ProLA-MS & Local government (SPCS)/7 Park Managers \\
\hline \multirow{6}{*}{ Community groups } & $\mathrm{PCPDC}^{(\mathrm{H})}$ & Parson Cross Park Development Community/member \\
\hline & $\operatorname{FoMFP}^{(\mathrm{H})}$ & Friends of Manor Field Park/member \\
\hline & FoHHP ${ }^{(M)}$ & Friends of High Hazels Park/member \\
\hline & FoRP $(\mathrm{M})$ & Friends of Richmond Park/member \\
\hline & MBPUT $^{(L)}$ & Meersbrook Park Users Trust/member \\
\hline & FoBHP ${ }^{(L)}$ & Friends of Bolehills Park/member \\
\hline
\end{tabular}

$\mathrm{H}=$ High, $\mathrm{M}=$ Middle, and L = Low deprived areas sourced from DCLG, 2015 [67].

Five interviews and one focus group were carried out with professional stakeholders who were closely involved in parks management at the local government. Local governments such as Sheffield's Parks and Countryside Service (SPCS) play a significant role as the landowner and principle manager of urban green space [68], and therefore play a key role in the long-term future of parks [27]. The local government often oversees the maintenance and management, while it is increasingly recognised that local residents and community groups should be involved in the process [33]. Community groups 
involved in the management of Sheffield's green spaces organise themselves into friends groups or park user groups [46,69]. In this research, there were around 80 community groups involved in green spaces in Sheffield at the time [70]. Each friends group will have varying characteristics or perceptions based on their skills and resources (Tables 2 and 3) [71]. The activities and perceptions of community groups can differ by park, depending on socio-demographic and environmental drivers [72,73], the characteristics of their neighbourhoods [74], and their relationship with local government [75].

Third-sector involvement has been increasing in park management [35], and has long been the case in Sheffield. To reflect this, the perceptions of one social enterprise were gleaned, as they manage one of the six parks selected for study. Finally, the university, with its great number of academics, has contributed to local knowledge-based growth [76], institutional changes [77], and local development [78] towards a strong emphasis on regional engagement. In this way, the University of Sheffield (specifically the Department of Landscape Architecture) is engaged in research on green space management within the local context. To reflect this, this study involved two interviews with academics. Overall, interviews were conducted with nine local government representatives, six community group representatives, a third-sector social enterprise, and two university academics (Table 1). Interviews were around 50-60 $\mathrm{min}$ in duration. Participants gave their consent to the researchers to audio-record the interviews and use the data for research and publication purposes.

\subsection{Data Collection and Analysis}

To explore how interviewees perceived urban park management in urban parks and the issues for future urban parks, a set of interview questions were designed. The relevant open question asked were:

- What has changed in parks management over the last 10 to 20 years?

- What is your opinion on alternative management in parks?

- How would you manage your park differently?

We conducted thematic analysis to examine the interviewees' perceptions and identified, analysed, and reported emergent themes $[79,80]$. This allowed us to scrutinise the data systematically for patterns to permit us to describe the phenomena under examination [81]. We followed thematic analysis guidelines established by NatCen (2012) to allow us to explore the data and develop explanations [82].

\subsection{Analytical Frameworks: Place-Keeping}

We conceptualised the thematic analysis conducted in this research within the place-keeping analytical framework, given the emerging and overlapping issues around urban park management. Analytical frameworks generally provide researchers with the opportunity to draw on creative thinking and achieve novel outcomes [83]. The literature reviewed in this research shows the potential applicability of place-keeping in urban park management contexts, employing the dimensions of policy, governance, funding, partnership, maintenance, and evaluation. It allows for understandings of park management, including the embodied processes and the wider context or "place" (Figure 1). This study acknowledges that place-keeping is not the only analytical framework that could have been applied; however, it was considered suitable for testing, given its recent application elsewhere [27] and ongoing exploration by the authors [21]. 
Table 2. Characteristics of the district park study sites (PCP, MFP, and HHP).

\begin{tabular}{cccc}
\hline Characteristics & Parson Cross Park (PCP) & Manor Fields Park (MFP) & High Hazels Park (HHP) \\
\hline Measure of deprivation * & 352 & 420 & 100 and 14,187 \\
\hline No. of years established & 70 & 1998 & 124 \\
\hline Comm. group established & 1999 & $15 / 50$ & 1988 \\
\hline Active/total no. members & $2 / 5$ & $\begin{array}{c}\text { Regular maintenance activity Fundraising Organising } \\
\text { events Sharing ideas for better parks Evaluating park } \\
\text { standards e.g., survey Managing charity shop }\end{array}$ & $\begin{array}{c}\text { Improvement of facilities e.g., tennis Involved in family } \\
\text { development project }\end{array}$ \\
\hline Types of activities & Managing venue for funding Organising 15 \\
activities per year & * From the national indices of multiple deprivation, where 1 is the most deprived and 32,841 is the least deprived [67].
\end{tabular}

${ }^{*}$ From the national indices of multiple deprivation, where 1 is the most deprived and 32,841 is the least deprived [67].

Table 3. Characteristics of the district park study sites (RP, MBP, and BHP).

\begin{tabular}{cccc}
\hline Characteristics & Richmond Park (RP) & Meersbrook Park (MBP) \\
\cline { 1 - 3 } Measure of deprivation & 16,564 and 8637 & 21,924 and 18,455 \\
\hline No. of years established & 50 & 130 \\
\hline Comm. group established & 2006 & 1998 \\
\hline Active/total no. members & $7 / 32$ & $20 / 300$ & 27,442 \\
\hline Types of activities & $\begin{array}{c}\text { Regular maintenance Fundraising Organising } \\
\text { events Improvement of facilities e.g., } \\
\text { tennis, toilets }\end{array}$ & $\begin{array}{c}\text { Regular maintenance Fundraising Improvement of facilities } \\
\text { e.g., playground, skateboard, football, dog bins Walled } \\
\text { garden management }\end{array}$ & $\begin{array}{c}\text { Regular maintenance Fundraising Organising events } \\
\text { Bridging role between council and residents Providing } \\
\text { ideas for better park }\end{array}$ \\
\hline
\end{tabular}




\section{Understanding Driver Changes of Park Management: It Starts with Policy}

The literature review highlighted how, in theory, place-keeping gives the different dimensions of partnership, governance, policy, evaluation, design/maintenance, and funding equivalent importance and weight $[33,36]$. However, this research challenges this by identifying different degrees of impact for each dimension when considering the context of district park management in Sheffield. The analysis of interview data reveals that a hierarchy emerges in terms of the relevance and value of each place-keeping dimension, with policy holding a dominant position over other dimensions (Figure 2).

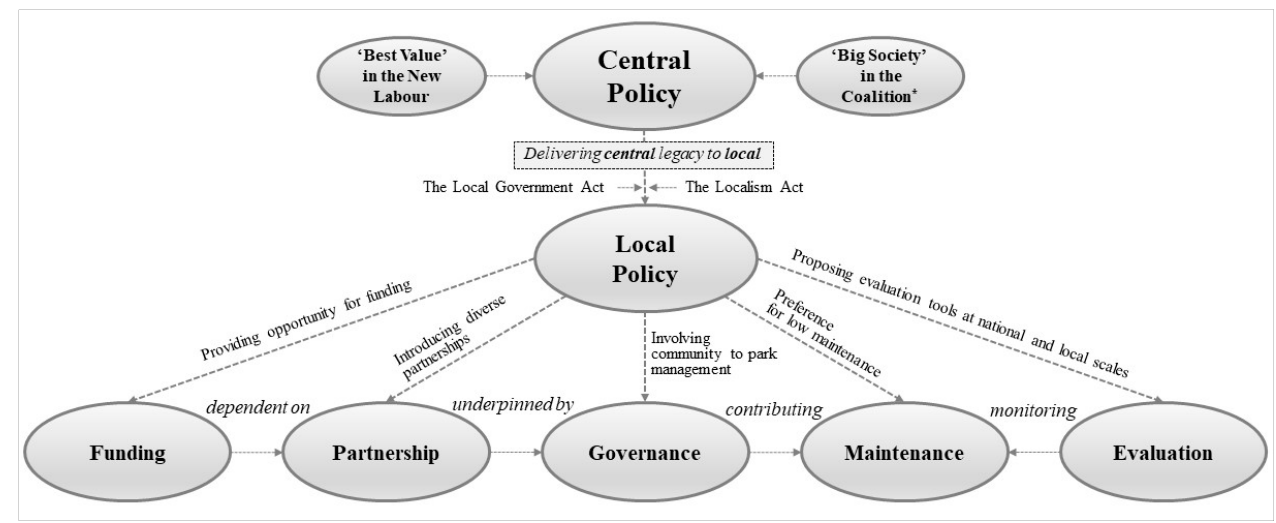

Figure 2. Applying a hierarchy of place-keeping dimensions in district urban parks management in Sheffield.

The discussion below outlines how understanding the interrelationships between dimensions of place-keeping permits a full understanding of the concept and the importance of context (Table 4).

Table 4. Emergent themes from the interviews around issues of park use and management, health, and well-being. CCT: Compulsory Competitive Tendering.

\begin{tabular}{|c|c|c|c|c|c|}
\hline $\begin{array}{l}\text { Corresponding } \\
\text { Place-Keeping } \\
\text { Dimension }\end{array}$ & Themes & IA * & $\begin{array}{c}\text { Corresponding } \\
\text { Place-Keeping } \\
\text { Dimension }\end{array}$ & Themes & IA \\
\hline \multirow[b]{2}{*}{ Partnership } & Extended partnership & & Maintenance & $\begin{array}{l}\text { Emphasis on regular } \\
\text { maintenance }\end{array}$ & \\
\hline & $\begin{array}{c}\text { Increasing involvement of private } \\
\text { sectors }\end{array}$ & & Site context & $\begin{array}{l}\text { Increasing anti-social } \\
\text { behaviours and vandalism }\end{array}$ & \\
\hline \multirow{3}{*}{ Governance } & $\begin{array}{l}\text { Empowered community in } \\
\text { decision-making }\end{array}$ & & \multirow{3}{*}{ Evaluation } & $\begin{array}{l}\text { Simplifying what gets } \\
\text { measured e.g., no. of } \\
\text { grass cuts }\end{array}$ & \\
\hline & $\begin{array}{l}\text { Increasing pressure on } \\
\text { community-led fundraising }\end{array}$ & & & $\begin{array}{l}\text { Requires references to the } \\
\text { local contexts }\end{array}$ & \\
\hline & $\begin{array}{c}\text { More reliance on community in park } \\
\text { management }\end{array}$ & & & $\begin{array}{l}\text { Creation of feasible, low-cost } \\
\text { evaluation tool(s) }\end{array}$ & \\
\hline
\end{tabular}

* Interviewee affiliation: PS public sector park managers, TS third sector, AC academics, CG community/friends groups. The shading indicates the broad extent to which this theme was discussed by the interviewees. 


\subsection{Policy}

The mid-20th century legacy of local government can be seen in the creation and ongoing management of urban parks in cities around the world. This legacy was significantly affected in the UK by the Conservative government, which introduced Compulsory Competitive Tendering (discussed above) in the 1980s. Meanwhile, the Sheffield City Council adopted its Sheffield Park Regeneration Strategy (SPRS) in 1993. The SPRS aimed to inform the management and planning of green spaces in Sheffield [84] via the creation of management plans and recommendations focussing on voluntary sector involvement, investment proposals, and monitoring use and appreciation.

As a reaction to the problems that CCT exacerbated in terms of deskilling parks management and reducing many tasks to grounds maintenance [85], the New Labour government (elected in 1997) introduced the Best Value regime. While this focussed on the quality of management, it put inordinate pressure on local governments to put resources into evaluating and measuring parks quality for national scrutiny (the then-Audit Commission). The local government was no longer solely responsible for parks management after the Localism Act (2011) was introduced by the (Conservative and Liberal Democrat) Coalition government of 2010, which created a national agenda around the "Big Society", focussing on the formalised involvement of community, voluntary, and third-sector organisations [86,87]. Locally, Sheffield spent a number of years developing its Green and Open Space Strategy (which was published in 2010-just in time for national austerity measures to kick in) [88]. Therefore, central policy and its direction have been cascading down to local government policy to bring significant impacts on funding, governance, partnership, evaluation, and maintenance in the contexts of park management.

\subsection{Funding}

The funding cuts that UK local governments experienced in the 1980 to 1990s and again since 2010 is a significant issue that is regarded as one of the main reasons behind the decline in green space management and maintenance standards [63,71]. This has widespread agreement in the literature reviewed. The interviewees reiterate this; all the stakeholder types mentioned the severe impacts of budget and funding cuts when asked about changes in parks management:

"The local authorities [governments] have massive budget cuts. They're struggling to know how to deal with parks." - ProAC-1

“There was budget of about $£ 400$, which you may compare to maybe a district park, probably requiring somewhere $£ 80,000$ to $£ 200,000$. So there was no budget at all." —ProSE

“ ... the high funding level compared [to the] 1990s has been cut since around 2000. Maintenance costs could be $£ 1500-2000$ pounds per hectare to down [to] $£ 400-500$ per hectare because of significant funding cuts." - ProLA-1

A core feature of this policy is $\mathrm{CCT}$, which has already been referred to. Interviewees discussed how CCT indeed negatively influenced park management at the local level by cutting budgets, changing contract structures, and ultimately helping worsen the quality of parks:

“... something called compulsory competitive tendering came in from the government, which meant that parks management didn't necessarily have to happen 'in house' anymore. You had to bid. As a way of cost saving, parks management [was] carried out the cheapest way possible. Councils were required to put out their parks management tender. I think they were able to bid if they wanted it themselves, but it went to the cheapest person." - ProAC-1

"Because some of the work for some local authorities was bid on by contractors, there's not as much flexibility in actually being able to manage in a different way, because their budgets are tied up with someone else doing the work." —ProAC-1 
Here, extra work has often been conducted in parks by community groups: "We [FoRP] have taken stewardship in the park from the gate to this end here ... we are responsible for cutting the grass and hedges here after the contractors cut [the] main grass areas]." —FoRP

Repercussions of this were felt elsewhere in Sheffield in terms of staff reductions and, in particular, of reducing staff working on the ground at sites: "Obviously, there's fewer people on the ground, but it's also the pressure on the middle management that's the problem." -ProAC-2

Furthermore, this situation also caused a declining level in staff qualification: "Funding cuts caused [a] decreasing number of staff in parks. In Sheffield, the numbers also went down, and it affected dropping staff level." —ProLA-1

This research shows interesting findings that the legacy of CCT seemed to promote community involvement in park management: one community group described "[after CCT, the] financial problems were when we started [in] 2007-2008. Global went to economic crisis, slash grant money from [the] government was really reduced; [the] council had a lot less money to spend [and so] invited community groups." - FoHHP

\subsection{Partnership}

The interviewees discussed how partnerships have evolved in distinctive ways. By the 1990s, a more holistic approach to partnerships was introduced by local government regarding park management, emphasising the development of partnerships within the local community as well as in expanded sectors: "The collective management with partnerships ... you'd have the council. You'd have the Friends. You'd have other groups of interest come together and say, 'This is what we want from our park.' It's based around management ... as a holistic approach to management"-ProAC-1

In this research, it has been observed that partnerships tend to form complex and innovative collaborations with various sectors. For instance, within the city council, this has involved the housing development and parks departments: "There is an income stream that we are now exploring, which has come out ... of the partnership project. [It] is called [the] housing revenue account, [where] all of these houses are managed by the councils and generate rent." -ProSE

Along with the development of partnership and community involvement in park management, the potential for extended partnership-for instance, non-profit organisations within the third sector-also emerged: "The things around responsibility are [that the] council takes [a] step back. [There are] ongoing talks around [a] trust taking over the management of quite large areas green spaces in Sheffield" -FoBHP

"You have an opportunity to bring in other funding. It may be [a] Sheffield parks trust, [which] is where people might be willing to give money to it. Like a membership organisation. There may be a different type of management model which is more of a partnership across the city in terms of the trust rather than just being the council," —ProAC-1

Interestingly, the political climate when these interviewees were conducted meant that a trust did not take over any green space management, because there was no political support.

These partnerships may expand in time beyond engaging simply with local government and extend to diverse sectors, driving parks management in a non-traditional way compared to the long-standing and more conventional approach where central or local government would generally take the lead. 


\subsection{Governance}

Policy focus has promoted and supported autonomy in urban park management at the local scale, where communities are encouraged to contribute actively in the decision-making process and to get more involved all round. Such changes have been observed and described in the interviews where park management has been in a transitional phase and moving towards a more community-led approach since the early 1990s.

One professional stated: "Volunteers were not allowed to work on local authority [government] sites with your agreement. That changed in 1993. So, volunteer groups like 'friend groups' started work on small sections." —ProLA-1

The same professional mentioned that "[The] 'friends groups' strategy was delivering in park [management] and ... some friends groups were getting involved in direct maintenance." -ProLA-1

Such evidence, which continually announced friends groups to get involved in parks management in the 2000s, was found in the community interviews; for example: "I found an old newspaper cutting in my archives of an advert calling for volunteers for the park, and that was in 2002." —FoMFP

Many community groups reported that they now constitute a decisive part in the decision-making process for park development and management and engage with the local government through regular community meetings. A local government interviewee stated, "I think the stakeholders and the friends group, especially, have become more involved with the park maintenance. You know, they do now have an input. We go to friends and meet teams monthly and bimonthly." —ProLA-Ms

It is expected that this increase in autonomy given to community groups or local residents will continue. This transition affects the attitude of the local government, in that they are making an effort to get more people involved: "They [the local government] invite a number of stakeholder groups to contribute and it grew out, and it genuinely is our 'friends group'. It is autonomous; it has local residents on it and they manage themselves, but it required a bit of push." —ProSE

Having said all this, decision-making processes are still heavily dependent on the local government. One community group stated: "We have applied for licenses for events. Parks and Countryside Department provides those parks licenses... It is extremely unfair. Some parks are allowed to do things, but we are not allowed. We don't feel support[ed]. Everything is like such [a] battle." —FoRP

This dependence on the local government is apparent in the institutional working practices: "We agree with them [community groups] in writing what they are going to do, how they're going to do it, what training they need, and we will meet with them and assess them to make sure they've got all the equipment and that they're capable of carrying out these tasks [which are a prerequisite to organise events or other activities]." —ProLA-2

In addition, this research found that community engagement in park management faced some difficulties, as seen from the local government's perspective:

"It is welcomed, but it is very difficult to get [community engagement]." —ProSE

“Taking paid jobs [is] still inherent in people's mindset. That is a barrier. The wider community can be vociferous in opposition to change in the park, but they don't actively do anything." -ProLA-1 
In other cases, pressure on fundraising led by community groups can have negative impacts on their activities: “We've got all these wonderful facilities that now we're thinking [about] how are we going to actually keep them all running... They [friends of groups] are getting more and more frustrated at the moment, because they can't find the external funding." -ProLA-2

Nevertheless, it is obvious that in order to operate within the current paradigm of park management in a policy context of austerity, this local government needs to seek community engagement and support. Thus, sharing or transferring the decision-making powers to the community may continue.

\subsection{Maintenance}

The interviewees discussed policy changes and their effects on funding and maintenance, particularly where budget cuts affect park maintenance through changes to staff working practices.

"Budget is the big thing. What happened is that the budget is being reduced where we used to get a designated team in certain areas who would ... visit that site on a weekly basis. Its management might just be reactive now sometimes, especially during the winter months, where they might not need much maintenance, but some might just be grass cutting. Sometimes, it's just reactive now rather than a programmed approach. And that cuts the budget really. And I think also 20 years ago a lot of the park department had a permanent team there, and that is the difference of the last 10,15 years as we gradually moved to more mobile teams." - ProLA-Ms

This is argued to have led to negative perceptions by park users where they are exposed to poor maintenance and management in their parks: "Nobody's looking after it [parks]. It needs somebody there to manage the park. We used to have park keepers when we were little. We had park keepers or ground, they'd be in the park all day. Just making sure children were safe, enjoying stuff, playing safely, no graffiti, being looked after. Again, there's no money there to pay the park keepers anymore." —PCPDC

This can lead to poor park management, resulting in anti-social behaviour: "The park has changed the character of the area ... as a bit of a dumping ground for burnt out cars and lots of anti-social behaviour." -FoMFP

The interview statements reveal that communities represent a "partner" that is getting progressively more involved in park maintenance and that certain aspects of maintenance now tend to rely on community engagement: "They can help us contribute [by getting] involved in the practical maintenance side. Litter picking, maybe planting flower beds, tree planting, just general maintenance." —ProLA-2

However, the interviews also illustrated a lack of local government support by funding, and staff cuts negatively affected the quality of maintenance and communication between community groups and local government: " ... this morning, [the] contractor cut [some] grass, but not all the area ... They didn't cut this area [pointing to area of park] ... We told what is happening in [the] park to [the] head of parks [at the council], but they did not respond. Communication is very hard. That is our problem." -FoRP

In Sheffield, the local government requires park maintenance costs to be covered for a five-year period if community groups raise money (e.g., for new playground equipment). Therefore, this local policy context and the cascading aspects from national policy on governance and partnership have a significant impact on changes to park maintenance. 


\subsection{Evaluation}

This research shows that the goal of achieving certain standards for urban parks emerged within a particular policy context that sought to establish targets to support improvements in the quality of urban parks. This manifested itself as a focus on park evaluation from the central to the local government level.

To evaluate the quality of green spaces nationally, New Labour introduced a green spaces audit tool called Green Flag Award (GFA) in 1996 [62]. Through the Urban White Paper (2000), this was a "comprehensive programme to improve the quality of parks, play areas, and open spaces, including the introduction of a new Green Flag Awards scheme to encourage and recognise excellence" [89]. In practice, the GFA is often used to evaluate park management processes. One interviewee commented: "One thing is to have a management plan, and to assess this [GFA] generates serious ambitions in the task. One thing is to annually find out how far we got close [to] the number of the next stage. That [GFA] is a very valuable tool." -ProSE

However, the GFA was considered impractical in some cases. Another community groups mentioned: "[The] Green Flag Award tends to be very traditionally what they are looking for park assessments."-FoBHP. In addition, the GFA process tends to assess a limited time of management: "Green Flag is changing now to mystery shopping [when] people turn up randomly through the year ... I think good management is that quality is there all year round" -ProLA-1

Another interviewee talked about how GFA makes excessive demands: "Green Flag takes up now too much resource for us ... They [Judges] have to pull [an] awful lot of resources into the park that they are going to give the Green Flag Award." - ProSE

An evaluation scheme has since been developed for the Sheffield context by SPCS. The Green Flag Award was the basis of the independent park assessment tool developed called the "Sheffield Standard": a simplified standard to effectively assess Sheffield's green spaces. "What we have done locally is to introduce Sheffield Standard ... the idea is that Sheffield Standard will be applied over the years to all our sites, to bring them up to a minimum standard." -ProLA-2

The SS permits the evaluation of urban parks by both communities and local government. This process can reflect different views of assessment: "Some of the stakeholders and the 'friend groups' assess that [Sheffield Standard] with ourselves." -ProLA-Ms

Interviewees discussed how evaluation brings cost and time constraints. This research found a similar statement: "The problem is consultation ... evaluation. It takes time, and it takes money, and it takes resources. The council doesn't have that..." -ProAC-1

Another stated, "[Regarding Sheffield Standard], resources dictate that we [local government] just can't carry on the same way ... We realise that perhaps we can't sustain that". These statements suggest that in order to complete a local level evaluation, communities may have to help contribute (time) resources.

\section{Addressing the Status Quo of Urban Park Management}

This section relates the overall research findings from the perceptions of community groups and professionals to the wider body of knowledge. The findings provide a range of approaches presented within the place-keeping analytical framework, which in turn can allow for a set of approaches based on a holistic understanding of complexity (Table 5). The approaches will be applicable to parks and management processes nationally and internationally, well beyond the Sheffield context. 
Table 5. Emerging themes to address the issues of park use and management, health, and well-being.

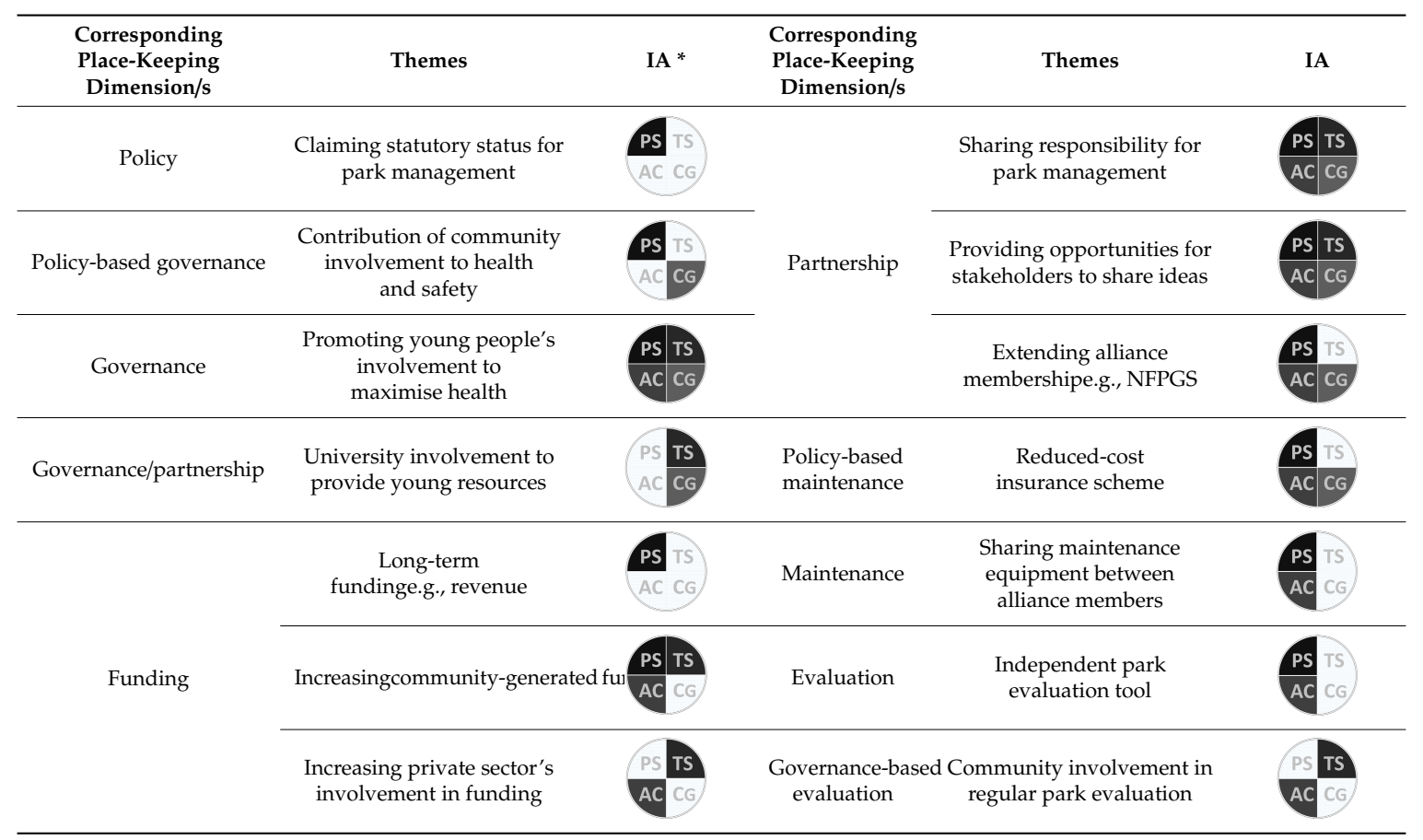

* Interviewee affiliation: PS public sector park managers, TS third sector, AC academics, CG community/friends groups. The shading indicates the broad extent to which this theme was discussed by the interviewees.

\subsection{Policy Contexts: Claiming Statutory Status for Park Management to Share Responsibility for Well-Being}

One obstacle to providing park management is lacking a statutory requirement for the provision of urban green space, as there is no ring-fenced funding to pay for it. A theme in the interviews emerged strongly that this should be secured by policy via statutory provision and an accompanying budget, which is underpinned by the perception that it can have a positive impact on people's health and well-being.

"We should make our green spaces a statutory provision. If we became a statutory provision by the government, then we would be more protected, but we're not. Our green space can be taken away because as money goes down in councils, there is less money for the non-statutory departments. That should be something that we're all campaigning for, to make parks and green spaces a statutory provision." - ProLA-2

The same professional commented, "It should be central government that says green spaces are so important for exercise, for well-being, for biodiversity, for everything. Take children out in outdoors classrooms, everything. Green space versus a school, park versus social services, cares for the elderly, there's only so much money. It should be a statutory provision." -ProLA-2

As outlined in the literature review, numerous studies show that green spaces and parks contribute positively to people's health and well-being, and this is not a new idea. The Public Health Act of 1875 indicated that green spaces help people's health and permitted local governments to create many parks in the UK's cities, although not with accompanying funding [90,91]. Local government interviewed here also identified the positive association between health and green spaces, stating: "The link to health is fundamental. We need to look down into how green space is [better] funded, because it is part of health." -ProLA-1

It is suggested that departments delivering statutory services such health should be involved in an expanding financial contribution to park management. The same interviewee commented: 
"[An] ideal park is [an] NHS-funded park. Everything else, all the recreations are a consequence of health ... NHS funds should fund parks with the proper construction of sports facilities and general recreational space." —ProLA-1

For instance, the Public Health Grants programme awarded funds to local government to use for green spaces and parks [92]. Health-related activities can also be part of the context for community involvement: "Today, money comes from football teams. They help us fund." -FoRP

Another interviewee stated, "For example, for our dementia project, [the] women's health group come. We write funding bids to get money." - PCPDC

A third said: "Any other groups getting involved in [park management] is XXXXX Well-being Community ... Obviously, key things are social services and health, [which are] taking priority" - FoHHP

In addition to these, the activity of community groups can help contribute to safer parks: "It may reduce crime and litter if we [community] are taking care of [a] small area." -MBPUP

\subsection{Governance in Approaches to How to Involve Young Volunteers}

As we have already outlined, there is a potential for green spaces to be considered active and positive places for young people to develop healthy physical activities [93], mental health [94], and social relationships [95], as well as an overall health-related quality of life [96]. In addition, volunteering is itself significantly related to promoting well-being and health [97]. This means that young people's volunteering involvement in green space management may help maximise their well-being and health, as well as addressing a lack of young people involved in park management. This research reflects the emerging issue that along with active community participation, the positive effects of engaging younger generations in volunteering have been underlined to contribute to effective green space management in the long term. Many of the community groups interviewed in this research have older members, pointing to a need for more people, and particularly young people, to get involved in park management.

"Who cares for parks? Most members of friends groups are very elderly. How will we care for parks in the next 10 years? ... We're getting older, and most members are over 70 years old." -FoHHP

However, this is a difficulty for the community groups interviewed here that do not have the capacity or knowledge of how to engage younger members. As one interviewee put it, "We want younger people to get involved, [but] we don't know how to engage with them to do it [park management]." - FoRP

However, in discussions about feasible approaches, different solutions were proposed, such as university involvement, a volunteering manager, and inviting young people already involved in other community groups.

The city's universities constitute key stakeholders, and can potentially contribute to park management in different ways. One professional stated, "The key stakeholder we have in management is actually the university landscape [architecture] department. That is probably the key, the only organisation we work with any interest whatsoever in the management" -ProSE

The university is suggested as a useful place to find young volunteers. University students already have been involved: "We get a couple of volunteers now. They are university volunteers coming on [date] working at the century garden"-FoHHP 
One community group stated: "We can get younger people involved. Younger people e.g., the university football team, get involved in ... they come on every Monday. It is just one hour. They are fantastic."-FoRP

However, it is noted that engaging local young people to parks is a different matter: "It is very difficult to get [young] people involved in the local park." —ProLA-2

Discussions in the interviews highlighted how a volunteer manager could help encourage more young people to get involved in parks. One professional interviewee stated, "We have a full-time volunteering manager and we have just changed the management structure of this park. We now have a young lady who would also come to friends meetings ... her job is to build volunteer and practical participation. So, she is now bringing [in] different groups." -ProSE

To do this, dedicated members of friends groups and staff are emphasised: "They [Manor Fields] have a dedicated member of staff to support them [friends group]." -ProLA-2

Another said, "This friends group [Manor Fields] is genuine, wanting to do something. Which is very good." - ProSE

In addition to inviting young people to volunteer in parks, one professional suggested approaching potential young volunteers from other types of groups, stating "They [young people] may join a different type of group ... It may be more around sports and active recreating in a park. Park runs that ... go on across Sheffield. That seems to be very popular with a great big age range. It may be building activities around and building that involvement around activities like that which [will] appeal to a broader population." —ProAC-1

Furthermore, appealing to active and young people to volunteer in their local parks should take priority, by means of both online and offline communication. The younger generations may need a more complex means of promotion to encourage their voluntary involvement with their local parks. A relevant example is the ongoing campaign by Groundwork Youth, \#GiveUsSpace, which uses social media as a way of promoting the active engagement of youth with their local parks. Such campaigns could be further promoted on the notice boards of the parks via QR (Quick Response) codes. This might encourage young people to join community groups through the use of technology and the social media, but further research would be needed to see if that would encourage younger residents effectively.

\subsection{Funding and Changing Mindsets?: Being Aware Of Community-Oriented Funding Opportunities}

Mindful of the necessity of funding, this research pinpoints some barriers to fundraising for park management. The first stems from a widely held belief that public green spaces and parks belong to everyone, making income generation by the public sector a difficult model to apply. Professionals and community groups tended to agree:

“... One big thing about green space is that it belongs to everybody. Just because you live around it doesn't mean that it's your park. Because they are open to everybody, you could go across the city and use every park. The thing that would worry me about introducing [a] levy on the public is that the public would see it's their park." —ProLA-2

Another said, "Users normally don't understand why I have to pay for them [public parks] to use [a] public area. They also pay council tax. They think it is unfair to [charge]." -MBPUT

"It [additional fundraising] is very difficult here; in other parts of the city, [it's] absolutely fine. Here, our main goal is to get people to use the space. So, it will be counterproductive to actually charge them. Most people actually just walk into the site, we got a tiny car park, we never considered car parking, just because it will be counterproductive" —ProSE 
This leads to the perceptions that local government should rely on a stable, long-term funding scheme, such as revenue funding (in the absence of council tax funding): “There is not [a scheme that is] very good at long-term funding for [the] future. It is still quite easy to get capital investment to sites for [a] new play area, new building, and something like that. Longer-term change would be needed in sites [that] are revenue-funded by day-to-day funding rather than [by] capital funding." - ProLA-1

Discussion in the interviews explored the opportunities for fundraising led by communities. This was considered alongside Sheffield's Green and Open Space Strategy and Community Infrastructure Levy, which represent city-scale frameworks within which funding for parks management can be levered: "What's happened is there has been a lot of money available for 'friends of' groups. We've had a lot of 'friends of' groups that have brought in money ... We have had $50 \%$ of our project cut in parks in countryside. We had to say to our 'friends groups' that we can only support them to bring in external money." —ProLA-2

This was echoed by an academic interviewee: "A lot of capital input went into parks. There were lots of initiatives about engaging communities ... to be involved in that parks management. 'friends groups' were involved and community groups [were] involved." -ProAC-1

The norm of taking responsibility for fundraising is increasingly commonplace for community groups: “They [local government] can't do anything about [funding] cuts ... more people make better parks maintained by [the] community." -MBPUT

Another said, "Friends of groups get quite involved because [the] council has no money to look after park. [The] friends group comes up [with] more funding." —FoBHP

Interviewees also discussed how park stakeholders should explore newly emerging funding opportunities involving the private sector: "So right from the very beginning, we had to think about how to use the park to generate income and we used the landscape, how we might build stakeholder participation." —ProSE

For instance, while a Park Improvement District piloted by the charity Nesta (2016) was not taken up in London, there may relevant adaptations that can be enacted to promote the private sector use of parks [98]. This is echoed in a growing body of research into the increase in commercial activities in parks, such as music festivals [99]. Keeping track of what policy changes mean for community groups and district parks governance and management is important: citywide umbrella organisations for groups such as the Birmingham Open Spaces Forum or Sheffield Green Space Forum (SGSF, formed in 2015) could become more strategic stakeholders as local government continues to struggle with budget cuts. Sharing knowledge in such forums is important for the sustainability of park management partnerships in order to deliver healthy green spaces and operate effectively to access capital and revenue funding, particularly if local government capacity is reduced.

\subsection{Partnerships: Sharing Locally and Sharing More Widely}

Interviewees discussed how the concept of shared responsibility varies through the actions of different interest groups in the Sheffield context. "Lots of interest [e.g., friends] groups tend to be still at the pressure group stage. A number of parks actually have [an] actively volunteering programme. However, they used to turn up on [any] day, not regularly and compulsorily. [But] Positively, 'friends groups' are usually actively involved in the management mindset. There are probably many good case studies about how groups can be very strongly involved." - ProLA-1 
It is noted that changes in perceptions are being prompted because of funding and budget changes. One professional stated that "their [local government] budget will be removed from them and possibly given to organisations like us [partners] or to friends groups. That's their fear ... that their money will be taken away and given somewhere else for someone to be used in different ways" - ProSE

This also relates to community groups and their everyday working practices: "Friends group come up [with] more funding. It [has] changed quite a bit" -FoBHP

However, the contribution of community groups can be restricted in terms if fundraising. One local government interviewee stated: "They [community groups] are getting more and more frustrated at the moment because they can't find the external funding." - ProLA-2

People need to be informed of what is happening in their local parks, which friends groups can help facilitate, as a local 'go-between' with local government. One community group discussed how "local people living near parks take more [of a] role helping ... in terms of how to maintain." -FoBHP

Another said that they are "sharing responsibility, all together, because government cuts [funding]. We have to work with councils ... we have to promote local responsibility, telling local people what is happening." - MBPUT

It is clear from the analysis of interviewees' responses that extending shared responsibility for park management can only be a positive development. The importance of park users' perceptions and a deeper understanding of shared park management should not be underestimated. Therefore, the local government as a potential facilitator and the community groups together need to appeal to people to get them more involved in park management, but this must be based on a better understanding of what already goes on in their own park.

Sharing ideas and knowledge through partnership and governance is often mentioned in relation to the local context of long-term management. However, as has already been stated in the literature, there is an emerging importance of forums linking communities with other stakeholders at wider scales $[69,100]$, by providing opportunities for stakeholders to share ideas. SGSF provides "[a] ... very good opportunity for communication between the local government and their community groups ... " - ProAC-1

They do this through a bi-monthly evening meeting of stakeholders who represent parks, community gardens, allotments, river corridors and other green spaces, the local government, the universities, and other organisations (e.g., police, wildlife trusts). One interviewee clarified regarding the Sheffield Green Space Forum that "the idea is that groups have got to become more self-sustaining and ... that the forum will help each other. The 'friends groups' who join the forum will then provide this support and expertise." -ProLA-2

The University of Sheffield is also involved in this forum as a facilitator, but not as an active decision-maker-only committee members have decision-making power, under the members' agreement. An academic interviewee stated that, "We were acting as facilitators. That was always our role. We weren't leading it. We weren't deciding exactly what they did. We were facilitating it. Now they have a committee. Really, it's up to them ... We can go on because we just did it from a research aspect... That [the forum] seems like a sensible model." -ProAC-1

There are difficulties for the forum that are encountered in any voluntary organisation. Firstly, it is difficult to find volunteers to sit on the management committee. At the time 
of the research, two committee positions, the Vice-Chairman and Treasurer, of SGSF were vacant due to different reasons (pregnancy and a sad and unexpected death), but there was little interest from members to stand in. Issues of replacement and succession are ongoing problems for volunteer groups found elsewhere [101]. Sharing knowledge and ideas may have limitations within the boundary of Sheffield, and there is a need for more communication with other forums (e.g., across Yorkshire, and the north of England), as well as with SGSF's representative national umbrella organisation, the National Federation of Parks and Green Spaces (NFPGS). "What benefit are they going to bring to more groups and for wider Sheffield green spaces rather than just being a small group of people like a friends group who are just focused on what they want to focus on?" -ProAC-1

To address these challenges, community groups need to be encouraged to regularly attend the SGSF and make connections with other forum meetings: for example, the revitalisation of forum groups by the local government, with a supporting team and alliance memberships at local and national levels. A programme of events and relevant guest speakers supported by a small joining fee could encourage more community groups to join these forums and gain access to a supporting network of contacts. Furthermore, promoting a local to national alliance could be the foundation for merging community groups or relevant stakeholders across cities, regions, nations, and beyond. National alliances such as the NFPGS and the recently established Parks Alliance promote networks with the support of the central government, although it is not currently clear how that support is manifested. There is clearly potential for coordination nationally through these organisations for political lobbying through a strong cross-sector alliance in the parks sector. Such a national partnership could have a great impact, as it could constitute the voice of different community groups, giving them the possibility to communicate their demands to local and central government and encourage variation in involvement by community groups in park management.

Sharing ideas and information can help improve the effectiveness of activities organised by community groups [102]. The interviews support the literature on how community groups perform different activities, from regular maintenance to fundraising in the context of contemporary park management [101]. We suspect that in the short term at least, this will be manifested as organising events and festivals in line with the move towards increases in fundraising for park management $[99,103]$.

\subsection{Encouraging Involvement in Maintenance through Parks Insurance}

New parks in the future may be designed for low maintenance, with limited options for park facilities and equipment, due to ongoing funding shortages. This raises issues around health and safety. Equipment, particularly in the play areas of parks, can be damaged and neglected due to budget cuts, because the local government alone is responsible for repairs and maintenance, representing a potential threat to users, particularly children. A park with zero-accident probability or where damaged equipment is immediately repaired represents the ideal scenario for children [104]. Unfortunately, however, putting this into practice is very difficult due to the lack of budget and staff to deal with the issues $[43,47]$. Equipment may be removed if there is no revenue funding for maintenance, potentially reducing user numbers. However, a rethink around low-cost maintenance and the health and safety for users may be delivered through community groups.

The type of parks insurance policy that has long insured local governments as green space managers can be extended to volunteers doing maintenance and enhancement work and damaged equipment. As part of the SGSF membership, SPCS provides a reduced-cost insurance scheme. Availability of the insurance scheme is restricted to active members of SGSF to incentivise involvement. For widespread availability, it is hoped that more community groups will get involved in SGSF, and therefore the insurance scheme will be extended. 


\subsection{Evaluation: Employing an Independent Park Evaluation Tool}

The ideal park management according to the interview analysis is "high park standards", regardless of the park type: "in an ideal world, every single green space should be managed to a high standard no matter where they are across the city." - ProLA-2

For this to be achieved, facilities and sustained resources are required. One professional stated that "most parks would want a cafe and a playground and what have you. Yes, in an ideal world. It would be great to have them all to a very high standard, beyond [the] Sheffield Standard, to have flowerbeds and fountains ... We could go on forever, putting in playgrounds and car parks so that everybody had a playground, a fountain, and a car park." -ProLA-2

To get closer to the ideal standard of parks, criteria for a reliable tool for evaluating park standards include objectivity and being based on existing evaluation tools, such as the Green Flag Award (GFA). The interviewees were largely positive about the independent local evaluation tool used here - i.e., the Sheffield Standard, which is to be used in partnership with stakeholders, particularly community groups and the university. It is clear that the GFA is considered a reliable evaluation tool at the national standard, but limitations have been identified when applying it locally. It is not feasible for all parks in a city to be GFA-winning, particularly in the context of austerity when resources and capacity are limited. The fundamental concept of the Sheffield Standard - to assure a minimum standard for all green spaces-is deeply linked to the GFA and its focus on retaining quality. "Our resources now will need to be put towards keeping those Green Flags rather than trying to get more, because we realise that perhaps we can't sustain that." - ProLA-2

Therefore, it is difficult in practice for all community groups to apply for the GFA, despite aspirations they might hold. The sharing of responsibility of self-assessments by community groups and local government, annual reviews of parks by local governments, and their annual audits, might be one step towards increasing quality in all green spaces across the city.

It is noted that as mentioned in previous sections, the city's universities represent a valuable stakeholder in park management contexts. Involving the universities could potentially contribute to implementing Sheffield park evaluations based on the research and skills of academics and volunteering experience of students. This is echoed by the academics interviewed: "if they [community groups] want us to evaluate how they're doing and make suggestions ... We're happy to do that." -ProAC-1

These evaluation tools need to be made available and accessible for any stakeholder to use-with verifiable and robust methods of data collection and collation. However, the resources required in terms of time and cost are considerable. There may be potential for this to be delivered by community groups and universities, particularly where it may support funding applications or help our understanding of how specific aspects of parks contribute to health and well-being (e.g., through social prescribing programmes).

\section{Lessons from Sheffield for Sustainable Urban Park Management}

The findings in this paper build on a growing body of research into place-keeping in different geographic contexts, including urban London [101], as well as rural and urban European settlements [33, 105,106]. Urban parks as green spaces can positively contribute to our health and well-being. However, this is dependent on spaces being well-managed. Therefore, the impact that current approaches taken to urban park management have on health and well-being must be more fully examined to provide effective solutions to sustainable management in the current era of austerity. We suggest that future research could explicitly explore the management of green spaces longitudinally to explore how 
changes might have an impact on health and well-being over time. We know that people's use of green spaces changes over the life course with exposure to nature in childhood being an important catalyst for green space use later in life [107], but we do not know how that influences their propensity to get involved in the management of urban nature.

Underpinned by the place-keeping framework, this research sought to better understand the current context of urban park management and address the issues derived from the financial crisis in the pursuit of long-term and sustainable concepts (Figure 3).

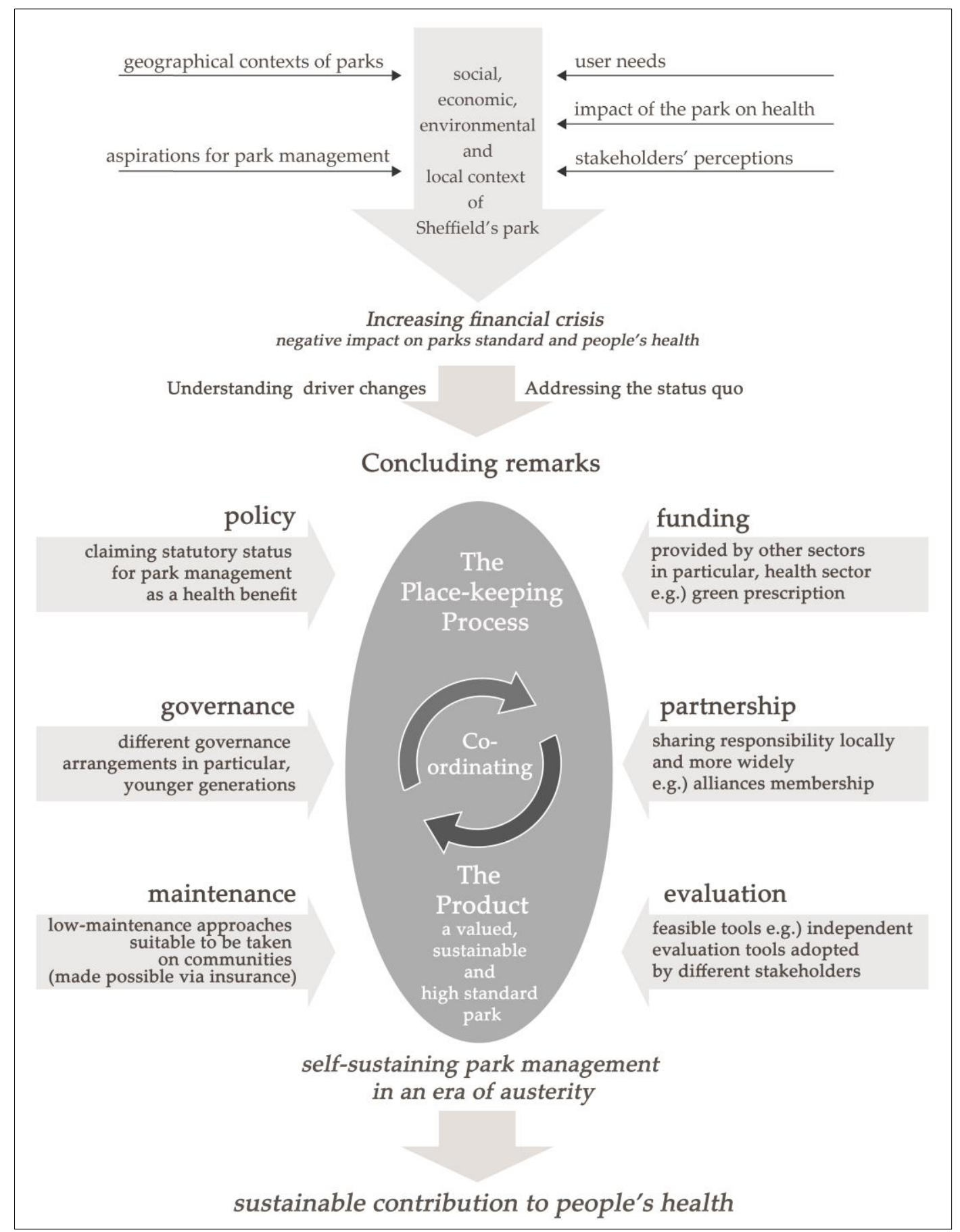

Figure 3. Conceptualisation of concluding remarks employing place-keeping analytical frameworks.

This research demonstrates the applicability of the place-keeping analytical framework showing the overarching impact of policy on park management. Policy informs funding that is increasingly 
dependent on partnerships, which are underpinned by governance contributing to a park's maintenance monitored through evaluation. However, policies without funding can jeopardise the effective management of parks, and the example of Sheffield's district parks shows how a single dimension cannot be taken, or addressed, in isolation. It shows how the idea for making park management a statutory service might have more traction if we consider its contribution to people's health. If this is taken seriously as a policy, then the responsibility and funding could be provided by other sectors that are under statutory provision in particular, health. One immediate way that researchers could explore this is through the health and well-being benefits to be harnessed through the active management and maintenance of urban green space as a 'green prescription' that is prescribed to patients with physical and mental health conditions. Non-medical interventions, or 'social prescribing', is being rolled out in the UK, attracting the interest of healthcare systems in Scandinavia, the United States (USA), Canada, and Australia [108]. This would involve different governance arrangements that bring with them health benefits, particularly volunteering and community involvement, and we have outlined how a concerted effort around engaging younger generations should form part of this.

The sharing of existing knowledge and ideas to effectively manage parks should be harnessed through park alliances at different (local to national) scales. The effectiveness of alliances could be the subject of future research monitoring and identifying gaps in capacity, tacit knowledge, and skills, as well as how they can be addressed. For such ongoing evaluation, feasible tools should be tested and adopted by different stakeholders, which will be relevant at local, citywide, and national scales, depending on the site. This research has shown how taking such a holistic approach that coordinates the different dimensions of long-term urban park management has the potential to make an important and sustainable contribution to our well-being and connection with urban nature.

Author Contributions: This paper is based on the first author's postdoctoral research conducted at the University of Sheffield under the supervision of the co-author. Both authors have contributed significantly to the paper.

Funding: This research received no external funding.

Conflicts of Interest: The authors declare no conflict of interest.

\section{References}

1. Chen, C.; Qin, Q. A research on the impact of urbanization on the residents' social behavior. Psychol. Sci. 2004, 27, 325-328.

2. Kaplan, R.; Kaplan, S. The Experience of Nature: A Psychological Perspective; Cambridge University Press: Cambridge, UK, 1989.

3. Hoyle, H.; Hitchmough, J.; Jorgensen, A. All about the 'wow factor'? The relationships between aesthetics, restorative effect and perceived biodiversity in designed urban planting. Landsc. Urban Plan. 2017, 164, 109-123. [CrossRef]

4. $\quad$ Ulrich, R.S.; Simons, R.F.; Losito, B.D.; Fiorito, E.; Miles, M.A.; Zelson, M. Stress recovery during exposure to natural and urban environments. J. Environ. Psychol 1991, 11, 201-230. [CrossRef]

5. Ball, K.; Timperio, A.F.; Crawford, D.A. Understanding environmental influences on nutrition and physical activity behaviors: Where should we look and what should we count? Int. J. Behav. Nutr. Phys. Act. 2006, 3, 33. [CrossRef] [PubMed]

6. Southon, G.E.; Jorgensen, A.; Dunnett, N.; Hoyle, H.; Evans, K.L. Perceived species-richness in urban green spaces: Cues, accuracy and well-being impacts. Landsc. Urban Plan. 2018, 172, 1-10. [CrossRef]

7. Shanahan, D.F.; Bush, R.; Gaston, K.J.; Lin, B.B.; Dean, J.; Barber, E.; Fuller, R.A. Health benefits from nature experiences depend on dose. Sci. Rep. 2016, 23, 28551. [CrossRef] [PubMed]

8. Deforche, B.; Van Dyck, D.; Verloigne, M.; De Bourdeaudhuij, I. Perceived social and physical environmental correlates of physical activity in older adolescents and the moderating effect of self-efficacy. Prev. Med. 2010, 50, S24-S29. [CrossRef] [PubMed]

9. Bragg, R.; Wood, C.; Barton, J.; Pretty, J. Let Nature Feed Your Senses: Engaging People with Nature, Food and Farming; Essex Sustainability Institute and Department of Biological Sciences, University of Essex: Essex, UK, 2012. 
10. Wilson, J.Q.; Kelling, G.L. Police and neighborhood safety. Broken windows. Atl. Mon. 1982, 127, $29-38$.

11. Burton, M.; Dempsey, N.; Mathers, A. Connecting making and keeping: Design and Management in Place-Keeping. In Place-Keeping: Open Space Management in Practice; Dempsey, N., Smith, H., Burton, M., Eds.; Routledge: Abingdon, UK, 2014; pp. 125-150.

12. Liu, H.; Li, F.; Li, J.; Zhang, Y. The relationships between urban parks, residents' physical activity and mental health benefits: A case study from Beijing, China. J. Environ. Manag. 2017, 190, 223-230. [CrossRef]

13. Berman, M.G.; Kross, E.; Krpan, K.M.; Askren, M.K.; Burson, A.; Deldin, P.J. Interacting with nature improves cognition and affect for individuals with depression. J. Affect. Disord. 2012, 140, 300-305. [CrossRef]

14. Raymond, C.M.; Berry, P.; Breil, M.; Nita, M.R.; Kabisch, N.; de Bel, M.; Enzi, V.; Frantzeskaki, N.; Geneletti, D.; Cardinaletti, M.; et al. An Impact Evaluation Framework to Support Planning and Evaluation of Nature-Based Solutions Projects. Report Prepared by the EKLIPSE Expert Working Group on Nature-Based Solutions to Promote Climate Resilience in Urban Area; Centre for Ecology \& Hydrology: Wallingford, UK, 2012.

15. Council of Europe. European Landscape Convention (European Treaty Series-No.176); Council of Europe: Florence, Italy, 2000.

16. Rostami, R.; Mohamad, S.; Khoshnava, M.; Rostami, R.; Bin Rosley, F. Sustainable Cities and the Contribution of Historical Urban Green Spaces: A Case Study of Historical Persian Gardens. Sustainability 2015, 7, 13290-13316. [CrossRef]

17. Randrup, T.; Persson, B. Public green spaces in the Nordic countries: Development of a new strategic management regime. Urban For. Urban Green. 2009, 8, 31-40. [CrossRef]

18. Douglas, O.; Lennon, M.; Scott, M. Green space benefits for health and wellbeing: A life- course approach for urban planning, design and management. Cities 2017, 66, 53-62. [CrossRef]

19. Randrup, T.; Östberg, J.; Wiström, B. Swedish green space management-The managers perspective. Urban For. Urban Green. 2017, 28, 103-109. [CrossRef]

20. Nam, J.; Dempsey, N. Community food growing in parks? Assessing the acceptability and feasibility in Sheffield, UK. Sustainability 2018, 10, 2887. [CrossRef]

21. Nam, J.; Dempsey, N. Understanding stakeholder perceptions of acceptability and feasibility of formal and informal planting in Sheffield's district parks. Sustainability 2019, 11, 360. [CrossRef]

22. MacKenzie, A.; Pearsonb, L.J.; Pearson, C.J. A framework for governance of public green spaces in cities. Landsc. Res. 2018, 44, 444-457. [CrossRef]

23. Falkner, R. Private environmental governance and international relations: Exploring the links. Glob. Environ. Politics 2003, 3, 72-87. [CrossRef]

24. Butler, A. Dynamics of integrating landscape values in landscape character assessment: The hidden dominance of the objective outsider. Landsc. Res. 2016, 41, 239-252. [CrossRef]

25. Arts, B.; Leroy, P. Institutional Dynamics in Environmental Governance; Springer: Dordrecht, The Netherland, 2006; Volume 1, pp. 1-294.

26. Ayana, A.N.; Vandenabeele, N.; Arts, B. Performance of participatory forest management in Ethiopia: Institutional arrangement versus local practices. Crit. Policy Stud. 2015, 11, 19-38. [CrossRef]

27. Mattijssen, T.; Buijs, A.; Elands, B.; Arts, B. The 'green' and 'self' in green self-governance-A study of 264 green space initiatives by citizens. J. Environ. Policy Plan. 2018, 20, 96-113. [CrossRef]

28. Bulkeley, H. Cities and the governing of climate change. Annu. Rev. Environ. Resour. 2010, 35, $229-253$. [CrossRef]

29. Barnes, M.; Skelcher, C.; Beirens, H.; Dalziel, R.; Jeffares, S.; Wilson, L. Designing Citizen-Centred Governance; Joseph Rowntree Foundation: York, UK, 2008.

30. Burton, M.; Mathers, A. Collective Responsibility for Place-Keeping: Are Partnerships the Solution for Open Space Management? In Place-Keeping: Open Space Management in Practice; Dempsey, N., Smith, H., Burton, M., Eds.; Routledge: Abingdon, UK, 2014.

31. Howard, P.; Thompson, I.; Waterton, E.; Atha, M. Landscape and Participation the Routledge Companion to landscape Studies; Routledge: New York, NY, USA, 2013.

32. Roberts, P. Shaping, making and managing places: Creating and maintaining sustainable communities through the delivery of enhanced skills and knowledge. Town Plan. Rev. 2009, 80, 437-453. [CrossRef]

33. Dempsey, N.; Burton, M. Defining place-keeping: The long-term management of public spaces. Urban For. Urban Green. 2012, 11, 11-20. [CrossRef] 
34. Wild, T.C.; Ogden, S.; Lerner, D.N. An Innovative Partnership Response to the Management of Urban River Corridors-Sheffield's River Stewardship Company. In Proceedings of the 11th International Conference on Urban Drainage, IAHR/IWA, Edinburgh, UK, 23 September 2018.

35. Dempsey, N.; Burton, M.; Duncan, R. Evaluating the effectiveness of a cross-sector partnership for green space management: The case of Southey Owlerton, Sheffield, UK. Urban For. Urban Green. 2016, 15, 155-164. [CrossRef]

36. Dempsey, N.; Burton, M.; Mathers, A. Place-keeping-responsive, long- term open space management. Town Ctry. Plan. 2012, 81, 431-436.

37. De Magalhães, C.; Carmona, M. Dimensions and models of contemporary public space management in England. J. Environ. Plan. Manag. 2009, 52, 111-129. [CrossRef]

38. MHCLG. $£ 1$ Million Funding for Communities to Create Their Own Pocket Parks. HM Government, 2018. Available online: https:/www.gov.uk/government/news/1-million-funding-for-communities-to-create-theirown-pocket-parks (accessed on 18 June 2019).

39. Kotulla, T.; Denstadli, J.M.; Oust, A.; Beusker, E. What Does It Take to Make the Compact City Liveable for Wider Groups? Identifying Key Neighbourhood and Dwelling Features. Sustainability 2019, 11, 3480. [CrossRef]

40. Dobson, J. From contest to context: Urban green space and public policy. People Place Policy 2018, 12, 72-83. [CrossRef]

41. Dempsey, N.; Dobson, J. Naturally Challenged: Contested Perceptions and Practices in Urban Green Spaces; Springer: Basel, Switzerland, 2019; forthcoming.

42. Heritage Lottery Fund. State of UK Public Parks 2014; Heritage Lottery Fund: London, UK, 2014.

43. Heritage Lottery Fund. State of UK Public Parks 2016; Heritage Lottery Fund: London, UK, 2016.

44. Ward Thompson, C.; Elizalde, A.; Cummins, S.; Leyland, A.H.; Botha, W.; Briggs, A.; Tilley, S.; Silveirinha de Oliveira, E.; Roe, J.; Aspinall, P.; et al. Enhancing Health Through Access to Nature: How Effective are Interventions in Woodlands in Deprived Urban Communities? A Quasi-experimental Study in Scotland, UK. Sustainability 2019, 11, 3317. [CrossRef]

45. Carmona, M.; De Magalhaes, C.; Blum, R.; Hopkins, J. Is the Grass Greener? Learning from International Innovations in Urban Green Space Management; CABE Space: London, UK, 2004.

46. Bretzer, Y.N.; Persson, B.; Randrup, P.B. Is public procurement efficiency conditioned by market types? A critical test in park and road sectors in Sweden. Int. J. Public Sect. Manag. 2016, 29, 488-501. [CrossRef]

47. CABE Space. Paying for Parks: Eight Models for Funding Urban Green Spaces; Commission for Architecture and the Built Environment: London, UK, 2006.

48. Lindholst, A.C. Contracting-out in urban green-space management: Instruments, approaches and arrangements. Urban For. Urban Green. 2009, 8, 257-268. [CrossRef]

49. Newcastle City Council. Newcastle Parks Trust. 2018. Available online: https://www.newcastle.gov.uk/sites/ default/files/Libraries\%20\%26\%20Hubs/Parks\%20\%26\%20Open\%20Spaces/3.Public\%20Presentation\% 20(Governance)\%20-\%20July\%202018.pdf (accessed on 18 June 2019).

50. Whitten, M. Blame it on austerity? Examining the impetus behind London's changing green space governance. People Place Policy 2019, 12, 204-224. [CrossRef]

51. Pillemer, K.; Fuller-Rowell, T.E.; Reid, M.C.; Wells, N.M. Environmental Volunteering and Health Outcomes over a 20-Year Period. Gerontologist 2010, 50, 594-602. [CrossRef]

52. Findlay-King, L.; Nichols, G.; Forbes, D.; Macfadyen, G. Localism and the Big Society: The asset transfer of leisure centres and libraries-Fighting closures or empowering communities? Leis. Stud. 2018, 37, 158-170. [CrossRef]

53. De Magalhaes, C.; Trigo, S. Contracting out publicness: The private management of the urban public realm and its implications. Prog. Plan. 2017, 115, 1-28. [CrossRef]

54. Boyne, G.A. Competitive Tendering in Local Government: A Review of Theory and Evidence. Public Adm. 2002, 76, 695-712. [CrossRef]

55. Delgado, A.; Strand, R. Looking North and South: Ideals and realities of inclusive environmental governance. Geoforum 2010, 41, 144-153. [CrossRef]

56. Murdoch, J.; Abram, S. Defining the Limits of Community Governance. J. Rural Stud. 1998, 14, 41-50. [CrossRef] 
57. Wilson, O.; Hughes, O. Urban Green Space Policy and Discourse in England under New Labour from 1997 to 2010. Plan. Pract. Res. 2011, 26, 207-228. [CrossRef]

58. Buizer, M.; Van Herzele, A. Combining deliberative governance theory and discourse analysis to understand the deliberative incompleteness of centrally formulated plans. For. Policy Econ. 2012, 16, 93-101. [CrossRef]

59. Gearey, M.; Ravenscroft, N. The Nowtopia of the riverbank: Elder environmental activism. Environ. Plan. E Nat. Space 2019. Accepted/In press.

60. Brindley, P.; Cameron, R.W.; Ersoy, E.; Jorgensen, A.; Maheswaran, R. Is more always better? Exploring field survey and social media indicators of quality of urban greenspace, in relation to health. Urban For. Urban Green. 2019, 39, 45-54. [CrossRef]

61. Carmona, M.; De Magalhães, C. Public Space Management: Present and Potential. J. Environ. Plan. Manag. 2006, 49, 75-99. [CrossRef]

62. Greenhalgh, L.; Parsons, A. Raising the Standard: The Manual of the Green Flag Award (updated); The Civic Trust: London, UK, 2004.

63. Barber, A. Green Future: A study of the Management of Multifunctional Urban Green Spaces in England; Green Space Forum: Reading, UK, 2005.

64. Adair, A.; Berry, J.; McGreal, S.; Deddis, B.; Hirst, S. The financing of urban regeneration. Land Use Policy 2000, 17, 147. [CrossRef]

65. Bovaird, T.; Loeffler, E. From engagement to co-production: The contribution of users and communities to outcomes and public value. Voluntas 2012, 23, 1119-1138. [CrossRef]

66. Carmona, M. Contemporary Public Space: Critique and Classification, Part One: Critique. J. Urban. Des. 2010, 15, 123-148. [CrossRef]

67. DCLG. English Indices of Deprivation; Department for Communities and Local Government: London, UK, 2015.

68. Van der Jagt, A.P.N.; Elands, B.H.M.; Ambrose-Oji, B.; Gerőházi, E.; Steen Møller, M. Participatory governance of urban green space: Trends and practices in the EU. Nord. J. Archit. Res. 2016, 3, 11-39.

69. National Federation of Parks and Green Spaces. 2018. Available online: https://www.natfedparks.org.uk/ (accessed on 10 June 2019).

70. Kumar, R. Research Methodology: A Step-By-Step Guide for Beginners; SAGE Publications Ltd.: London, UK, 1999.

71. Jones, R. Theme: Local Government: With a Little Help from My Friends: Managing Public Participation in Local Government. Public Money Manag. 2002, 22, 31-36. [CrossRef]

72. Bell, S.; Tyrväinen, L.; Sievänen, T.; Pröbstl, U.; Simpson, M. Outdoor recreation and nature tourism: A European perspective. Living Rev. Landsc. Res. 2007, 1, 1-46. [CrossRef]

73. Kaczynski, A.T.; Henderson, K.A. Environmental correlates of physical activity: A review of evidence about parks and recreation. Leis. Sci. 2007, 29, 315-354. [CrossRef]

74. Glaser, M.; Denhardt, K. Local government-sponsored community development: Exploring relationships between perceptions of empowerment and community impact. Am. Rev. Public Adm. 1997, 27, 76-94. [CrossRef]

75. Berman, E. Dealing with cynical citizens. Public Adm. Rev. 1997, 57, 105-112. [CrossRef]

76. Asheim, B.T.; Isaksen, A.; Nauwelaers, C.; Todtling, F. Regional Innovation Policy for Small-Medium Enterprises; Edward Elgar: Surrey, UK, 2003.

77. Chatterton, P.; Goddard, J. The Response of Higher Education Institutions to Regional Needs. Eur. J. Educ. 2000, 35, 475-496. [CrossRef]

78. Feldman, M.; Desrochers, P. Research Universities and Local Economic Development: Lessons from the History of the Johns Hopkins University. Ind. Innov. 2003, 10, 5-24. [CrossRef]

79. Donovan, J.; Sanders, C. Key Issues in the Analysis of Qualitative Data. In Handbook of Health Research Methods: Investigation, Measurement and Analysis; Bowling, A., Ebrahim, S., Eds.; Open University Press: Maidenhead, UK, 2005; pp. 520-521.

80. Braun, V.; Clarke, V. Using thematic analysis in psychology. Qual. Res. Psychol. 2006, 3, 77-101. [CrossRef]

81. Tesch, R. Qualitative Research: Analysis Types and Software Tools; Falmer Press: London, UK, 1990; p. 51.

82. NatCen Learning. The Framework Approach to Qualitative Data Analysis; NatCen Learning: London, UK, 2012.

83. Coral, C.; Bokelmann, W. The Role of Analytical Frameworks for Systemic Research Design, Explained in the Analysis of Drivers and Dynamics of Historic Land-Use Changes. Systems 2017, 5, 20. [CrossRef]

84. Sheffield City Council. Sheffield Park Regeneration; Sheffield City Council: Sheffield, UK, 1993. 
85. Dempsey, N.; Burton, M.; Selin, J. Contracting Out Parks and Roads Maintenance in England. Int. J. Public Sect. Manag. 2016, 29, 441-456. [CrossRef]

86. DCLG. The Localism Act 2011; Department for Communities and Local Government: London, UK, 2011.

87. Mabbutt, A. The Conservative Party Manifesto; St. Ives PLC: London, UK, 2015.

88. Sheffield City Council. Sheffield's Great Outdoors: Green Space E Open Space Strategy 2010-2030; Sheffield City Council: Sheffield, UK, 2010.

89. ODPM; DCLG. Our Towns and Cities: The future. The Urban White Paper; Office of the Deputy Prime Minister: London, UK, 2000.

90. UK Parliament. The Public Health Act 1875; UK Parliament: London, UK, 1857. Available online: http: //www.legislation.gov.uk/ukpga/1875/55/pdfs/ukpga_18750055_en.pdf (accessed on 10 March 2019).

91. Layton-Jones, K. History of Public Park Funding and Management (1820-2010); Historic England: London, UK, 2016.

92. DHPHE. Public Health England's Grant to Local Authorities; Department of Health and Public Health England: London, UK, 2014.

93. Ward, J.S.; Duncan, J.S.; Jarden, A.; Stewart, T. The Impact of Children's Exposure to Greenspace on Physical Activity, Cognitive Development, Emotional Wellbeing, and Ability to Appraise Risk. Health Place 2016, 40, 44-50. [CrossRef]

94. Gascon, M.; Triguero-Mas, M.; Martinez, D.; Dadvand, P.; Forns, J.; Plasencia, A.; Nieuwenhuijsen, M.J. Mental Health Benefits of Long-Term Exposure to Residential Green and Blue Spaces: A Systematic Review. Int. J. Environ. Res. Public Health 2015, 12, 4354-4379. [CrossRef]

95. Kelley, M.; Pendras, M.; Minnella, H. Sketching culture, sketching nature: Uncovering anchors of everyday nature for urban youth. Soc. Cult. Geogr. 2012, 13, 873-893. [CrossRef]

96. Kim, J.H.; Lee, C.; Sohn, W. Urban Natural Environments, Obesity, and Health-Related Quality of Life among Hispanic Children Living in Inner-City Neighborhoods. Int. J. Environ. Res. Public Health 2016, 13, 121. [CrossRef]

97. Piliavin, J.A.; Siegl, E. Health Benefits of Volunteering in the Wisconsin Longitudinal Study. J. Health Soc. Behav. 2007, 48, 450-464. [CrossRef]

98. NESTA. We Rethought the Park; Nesta: London, UK, 2016.

99. Smith, A. Paying for parks. Ticketed events and the commercialisation of public space. Leis. Stud. 2018, 37, 533-546. [CrossRef]

100. CABE Space. Green Space Strategies a Good Practice Guide; CABE Space: London, UK, 2004.

101. Mathers, A.; Dempsey, N.; Molin, F.J. Place-keeping in action: Evaluating the capacity of green space partnerships in England. Landsc. Urban Plan. 2015, 139, 126-136. [CrossRef]

102. Hemmasi, M.; Csanda, C.M. The Effectiveness of Communities of Practice: An Empirical Study. J. Manag. Issues 2009, 21, 262-279.

103. Dempsey, N. Funding Flexible Space. In Staging Urban Landscapes: The Activation and Curation of Flexible Public Spaces; Ivers, B.C., Ed.; Birkhauser: Basle, Switzerland, 2018; pp. 54-57.

104. Ball, D.; Gill, T.; Spiegal, B. Managing Risk in Play Provision: Implementation Guide; National Children's Bureau: London, UK, 2012.

105. Dempsey, N.; Smith, H.; Burton, M. Place-Keeping: Open Space Management in Practice; Routledge: London, UK, 2014.

106. Mattijssen, T.; van der Jagt, A.; Buijs, A.; Elands, B.; Erlwein, S.; Lafortezza, R. The long-term prospects of citizens managing urban green space; in place making to place-keeping? Urban For. Urban Green. 2017, 26, 78-84. [CrossRef]

107. IWUN. Improving Wellbeing through Urban Nature (2019) Supporting People's Mental Wellbeing through Urban Nature-Challenging Inequalities. Available online: http://iwun.uk/findings/includinghttp://iwun.uk/ wp-content/uploads/2019/07/IWUN-Practice-Brief-Challenging-Inequalities.pdf (accessed on 6 June 2019).

108. Drinkwater, C.; Wildman, J.; Moffatt, S. Social prescribing. BMJ 2019, 364, 11285. [CrossRef]

(C) 2019 by the authors. Licensee MDPI, Basel, Switzerland. This article is an open access article distributed under the terms and conditions of the Creative Commons Attribution (CC BY) license (http://creativecommons.org/licenses/by/4.0/). 